O. Derkach, postgraduate student

Taras Shevchenko National University of Kyiv, Kyiv, Ukraine

\title{
QUALITY OF HIGHER EDUCATION IN POLAND IN THE TRANSFORMATION OF EDUCATION POLICY
}

The systematic changes in higher education institutions in Poland over the past two decades are analyzed. The classical idea of spontaneous social development and the hypothesis of interaction between formal and informal institutions, developed on the basis of a new institutional educational policy, was adopted as a methodological basis for analyzing and evaluating the transformation of Polish higher education. Transformations in Polish higher education are part of a more general shift in the role of universities - changes that can limit the independence of research and make it an instrument of dominant social, political and economic forces.

The article states that the process of improving the quality of education cannot be detached from the system of financing education. The quality of education depends on the funding system not only because it is a source of resources, but also because it creates incentives for both students and teachers. The problems in the field of financing higher education in Poland are special because the rapid quantitative development of higher education occurred during a period of deep political transformation in Poland.

The activities of the State Accreditation Commission of Poland are analyzed, its main competences are highlighted. The Polish Accreditation Commission (Polska Komisja Akredytacyjna) is an independent collegiate body of higher education management aimed at improving the quality of education. It is formed by the Minister of Science and Higher Education from among the candidates proposed by the Council of the Conference of Rectors of Higher Education Institutions of Poland, the Conference of Rectors of Polish Professional Educational Institutions of Poland, the Parliament of Students of the Republic of Poland, the Senates of universities and national scientific societies and the organization of employers. The powers of the Commission include providing the Minister of Science and Higher Education with opinions, feedback and conclusions regarding the establishment of the HEl or its organizational unit, permits to study studies in a particular direction at one or another level of education; program and institutional assessment, including pedagogical education. The impact of financing higher education institutions to ensure the quality of higher education is partly considered in the article.

Keywords: higher education, quality of education, transformation, financing, the State Accreditation Commission.

УдК 378.2

DOI: https://doi.org/10.17721/2415-3699.2020.12.04

М. Жиленко, канд. пед. наук, доц. Київський національний університет імені Тараса Шевченка, Київ

\section{УМОВИ ЕФЕКТИВНОГО ДЕЛЕГУВАННЯ ПОВНОВАЖЕНЬ МЕНЕДЖЕРОМ ЗАКЛАДУ ВИЩОЇ ОСВІТИ}

Досліджено рівень готовності менеджера ЗВО до делегування своїх повноважень і узагальнено досвід такої діяльності. У ході вивчення діяльності проректорів, начальників відділів, деканів факультетів, директорів інститутів, навчально-наукових центрів закладу вищої освіти з'ясовано, що керівник (менеджер), як суб'єкт управління, повинен вміти проаналізувати ситуацію, спрогнозувати стратегію, спланувати тактику для досягнення визначених цілей і організувати оперативне управління з їхньої реалізації. Проте більшість із досліджуваних підходять до розв'язання цієї проблеми на рівні буденної свідомості, не завжди розуміють, що управління - це насамперед уміння організувати роботу в команді. Ефективність управлінської праці керівника в закладі вищої освіти здебільшого залежить від особистісних характеристик керівника, але обов'язковим компонентом їі продуктивності є компетентності, які не можуть бути сформовані без спещіальних знань. Порядок обрання та призначення на посаду наявності таких знань не передбачає. Менеджер закладу освіти практично не може впливати на рівень передбачуваності завдань, які мають зовнішню природу, у той час як професійна організація й упорядкування структури внутрішньої діяльності дає значні переваги. Одним із напрямів оптимізації структури внутрішньої діяльності управлінця та підвищення ії ефективності є готовність і уміння делегувати свої повноваження. Це в межах добре спланованої роботи дає можливість керівникові отримати найбільший резерв часу. Аналіз практики діяльності успішних менеджерів і наукової літератури з означеної проблеми дозволив сформулювати рекомендації керівникам для успішного делегування повноважень, які передбачають використання певних принципів делегування, чітке розуміння видів і обсягу діяльності, робіт, які можна делегувати; розуміння порядку і процедури визначення цілей і постановки завдань; урахування професійних можливостей персоналу. Доведено, що важливою умовою ефективного делегування є оволодіння керівником логікою формулювання і процедурою постановки розумних цілей, що має забезпечити напружений ритм для кожного працівника з урахуванням цілей діяльності, особистісних і професійних можливостей.

Ключові слова: структура внутрішньої діяльності, делегування, принципи делегування, концепція смарт, розумні цілі.

Постановка проблеми. В умовах модернізації системи вищої освіти в Україні, нормативно-законодавча база передбачає демократичну процедуру для зайняття посади керівника в закладах вищої освіти. У статті 42 Закону України "Про вищу освіту" сказано - обрання, призначення та звільнення з посади керівника закладу вищої освіти передбачає, що кандидат повинен вільно володіти державною мовою, мати вчене звання та науковий ступінь, стаж роботи на посадах науково-педагогічних працівників не менше як 10 років тощо. Для кандидата не передбачено вимог щодо наявності спеціальних знань з освітнього менеджменту [4], хоча в цьому ж Законі, у розділі 7 ст. 34, визначаються повноваження керівника закладу вищої освіти (пункт 3): організовує діяльність закладу; вирішує питання фінансово-господарської діяльності, затверджує його структуру і штатний розпис; видає накази й розпорядження, дає обов'язкові для виконання всіма учасниками освітнього процесу і структурними підрозділами доручення тощо, здійснює інші передбачені статутом повноваження [1]

Якщо порівняти вимоги до претендента і зміст його повноважень, стає очевидним, що для ефективного здійснення місії керівникові потрібен ряд компетентностей із планування і організації, якими, виконуючи обов'язки на посадах науково-педагогічних працівників, навіть 10 років, маючи науковий ступінь і вчене звання, відповідаючи іншим вимогам ст. 42 Закону, кандидат може не володіти. I тому, ураховуючи зміст повноважень керівника, дуже важливою компетентністю для нього $€$ здатність делегувати свої повноваження. Зараз у системі освіти працюють випускники освітніх програм з управління закладами освіти, які володіють необхідними компетентностям та програмними результатами навчання згідно зі стандартом вищої освіти, із яких керівник може створити команду і в такий спосіб підвищити рівень менеджменту в ЗВО [7]. Вивчення рівня готовності менеджера ЗВО до 
делегування своїх повноважень і узагальнення досвіду такої діяльності є метою цього дослідження.

Аналіз останніх досліджень і публікацій. Окремі аспекти управлінської праці в освітній сфері досліджувались різними науковцями: Г. О Оборський, В. Д Гогунський досліджували стандартизацію і сертиффікацію процесів управління якістю освіти, В. А. Рач, А. Ю. БорзенкоМірошніченко проєктно орієнтовані моделі управління й оцінки діяльності закладів вищої освіти, Л. М. Карамушка провела психологічний аналіз управління освітніми організаціями, С. Волянська, А. Остапенко досліджували професійну рефлексію керівника як фрактор успішного розвитку закладу освіти. Разом із тим, питання аналізу реального рівня готовності менеджера ЗВО до делегування своїх повноважень, уміння організувати роботу в команді й узагальнення досвіду такої діяльності не знайшли достатнього відображення.

Ця робота $€$ продовженням комплексного дослідження підходів до наукової організації праці керівника 3ВО, яке проводиться кафедрою педагогіки КНУ імені Тараса Шевченка в межах удосконалення освітньої програми ОС магістр "Управління закладом вищої освіти". Натепер уже проведено комплексну оцінку ефективності управлінської діяльності керівника закладу вищої освіти [1], досліджено використання принципів нейролінгвістичного програмування при підготовці менеджерів для освітньої сфери [2], організація особистої діяльності керівника, як умова ефективного управління закладом освіти [3], предметна галузь підготовки управлінців для системи вищої освіти.

Викладення основних положень. Проведене дослідження діяльності проректорів, начальників відділів (8), деканів факультетів, директорів інститутів, ННЦ (16) дозволило з'ясувати, що ефективність управлінської праці здебільшого залежить від особистісних характеристик керівника, але обов'язковим компонентом ії̈ продуктивності $є$ компетентності, які не можуть формуватися без спеціальних знань. Серед основних проблем, за підсумками дослідження, були визначені такі. Поняття, зміст і принципи наукової організації праці. Більшість респондентів вказали на потребу знань зі структури й нормативно-правового забезпечення управління закладом вищої освіти, із системи наукової організації управлінської праці, організації документообігу в управлінні 3ВО, наукових підходів до планування й організації діяльності.

У ході уточнювальних бесід з'ясувалося, що керівник (менеджер), як суб'єкт управління, повинен вміти проаналізувати ситуацію, спрогнозувати стратегію, спланувати тактику для досягнення визначених цілей і організувати оперативне управління з їхньої реалізації. Разом із тим, з'ясувалося, що більшість із досліджуваних підходять до розв'язування цієї проблеми на рівні буденної свідомості, не завжди розуміють, що управління - це насамперед уміння організувати роботу в команді. Лише незначна кількість учасників дослідження готові делегувати свої повноваження і практично всі не мають чітких уявлень, як це зробити ефективно.

Відомо, що діяльність керівника залежить від структури організації, його ієрархічного місця в цій структурі. Об'єктом організаційної поведінки керівника у ЗВО є науково-педагогічні працівники, студенти, керівники факультетів, інститутів, завідувачі кафедр, спеціалісти, працівники допоміжних служб, які $є$ основним капіталом ЗВО, оскільки від них залежить досягнення основних цілей організації.

Керівник не може вплинути на кількість, зміст і час виникнення проблем і завдань у діяльності ЗВО, або підрозділу закладу освіти. Що робити? Є шлях зовнішньої упорядкованості (але в сучасних умовах управлінські процеси у системі освіти мають високий рівень ентропії), менеджер закладу освіти практично не може впливати на стан їхньої передбачуваності. Залишається профе-сійна організація й упорядкування структури внутрішньої діяльності. Її знання дає переваги: бачити головне, що треба зробити для розв'язання завдання; бачити в будьякий час стан розв'язання проблеми; своєчасно вносити корективи; отримувати результат найбільш раціональним шляхом.

Уміння ощадливо витрачати час $є$ ознакою високої культури управління, вихованої й організованої людини. Закон менеджменту: чим більше часу керівник витрачає на планування, тим менше його йде на безпосереднє розв'язання проблеми, що заощаджує загальний час. Якщо на планування робочого дня витрачати 8-15 хвилин і послідовно дотримуватись плану, то щодня можна виграти одну годину часу [6]. Чим краще менеджер навчиться розподіляти (планувати) свій час, тим краще він зможете використати його для професійних і особистих цілей. Це його перевага у плануванні. Однак найбільший резерв часу керівник може отримати в межах добре спланованої роботи за рахунок правильного делегування свої повноважень.

У процесі дослідження було з'ясовано причини із яких більшість керівників уникають це робити. Не знають як, вважають, що це недоречно, зменшує керованість, владні повноваження, службовий авторитет. Вважають, що це складний і тривалий процес, вимагає додаткових зусиль для навчання, пояснення, контролю, що забирає багато часу. Краще зробити самому й нікому нічого не пояснювати, нікого не контролювати. Проте неможливість усе зробити або проконтролювати самому, практично завжди призводить до стану стресу або фрустрації, не кажучи про збільшення витрат службового й особистого часу.

Делегування - це передача персоналу завдання або діяльності зі сфери дії керівника одночасно з необхідною компетенцією та функціональною відповідальністю. Воно має однакові переваги як для керівника, так і для персоналу, але лише за умов, якщо дотримуватись певних принципів. 1. Діапазон контролю - оптимальна кількість персоналу, що підпорядкований одному керівникові, і яким він може ефективно управляти (визначається здібностями керівника, працівників, типом і важливістю роботи, розташуванням персоналу, ступенем його мотивації). 2. Фіксована відповідальність (в інструкції, посадових обов'язках) - звільнити від неї може лише керівник, що займає вищу посаду. 3. Відповідність прав і обов'язків (повноваження = відповідальності). 4. Делегування відповідальності на низи. 5. Звітність за відхиленням.

Для успішного делегування керівник має переконатися що персонал розуміє: навіщо цю роботу необхідно виконувати; чому ви доручаєте роботу саме їм; до якого терміну має бути виконана робота; на які самостійні рішення персонал має право; який попередній досвід може бути взірцем; які звіти по ходу роботи або після ії̈ завершення персонал має надати; засоби й допомога, які вони можуть отримати при виконанні роботи. Для того, щоб ці правила ефективно працювали, необхідна наявність певних умов: підбір персоналу; готовність (бажання) делегувати; розподіл сфер відповідальності (здатність, вміння делегувати); якщо потрібно - навчання, координація діяльності персоналу, що виконує доручене завдання; стимулювання й консультування; здійснення контролю за виконанням і результатами; обов'язкова оцінка роботи. Важливо для керівника розуміння, що об'єктом делегування мають бути рутинна робота, окремі питання, вузькоспеціалізована управлінська діяльність, роботи, що перебувають на підготовчій стадії. 
Для унаочнення можливостей оптимізації і систематизації процесу делегування нами було використано концепцію SMART. SMARTER - це мнемонічна абревіатура, що використовується в менеджменті і проєктному управлінні для визначення цілей і постановки завдань.

"S" Specific (конкретний) розуміння керівником, чого саме необхідно досягти. Наприклад, "підготувати пакет документів для ліцензування освітньої програми".

"M" Measurable (вимірюваний) здатність пояснити в чому вимірюватиметься результат. Якщо показник кількісний, необхідно визначити одиниці вимірювання, якщо якісний - визначити еталон для порівняння. Наприклад, "аспірантам першого року навчання до 01.02.20. року закоординувати тему дослідження в Міжвідомчій координаційній раді Національної академії педагогічних наук".

"A" Attainable, Achievable (досяжний) розуміння i вміння пояснити, за рахунок чого планується досягнути цілі (цілей). І чи можливо їх досягти взагалі? Наприклад, "методистам деканату, лаборантам кафедр у міжсесійний період оволодіти технологією роботи з базою даних університету "Тритон". Для цього інженеру фракультету А. В. 01.02. 20.. р. о 14.00 провести з цим персоналом групову консультацію, а в період з 02.02.20.. р. до 10.02.201... індивідуальні консультації. А ось створити власну автоматизовану базу факультету й інтегрувати їі в загальноуніверситетську навряд чи реально.

"R" Relevant (актуальний) розуміння, чи справді виконання цього завдання дасть змогу досягти поставленої мети? Необхідно переконатися, що його виконання справді необхідно. "Заступнику декана А. М. перевірити підготовленість до відпрацювання всіх видів навчальної документації, що визначені в наказі ректора "Про підготовку до 20../20.. навчального року", доповісти письмово про рівень підготовленості кожного методиста деканату й лаборанта кафедри".

"T" Time-bound (обмежений у часі) визначення реального часового тригера/проміжку з настання/закінчення якого має бути досягнуто мети. Наприклад, "у період з 1 по 15 березня 20.. року підготувати оперативні плани викладання дисциплін на факультеті у 1 семестрі, до 20 березня у 2 семестрі, до 30 березня заявки на забезпечення навчального процесу кафедрами фракультету, до 05 квітня кафредрами інших підрозділів університету у 20../20.. навчальному році.

Досягнення цілі залежить від її формулювання і перший крок до успіху справи - правильно сформульовані цілі. SMART цілі - розумні цілі. Що таке ціль? Ціль - це те, до чого прагнуть, чого хочуть досягти; призначення, сенс дій, що мають бути виконані; бажаний на цей момент стан будь-якого проєкту внаслідок виконаної роботи. Як необхідно ставити цілі, щоб вони були досяжними і з тим результатом, який необхідний керівникові? Цілі мають бути розумними. Що це означає? У практиці управління існують SMART-критерії, яким мають відповідати цілі.

Конкретність. Ставлячи завдання, насамперед треба поставити собі запитання: що ви хочете отримати внаслідок його виконання? Чому важливий саме цей критерій? У вас в голові формується своє бачення результату виконання задачі (ідея один - I1). По ходу викладення керівником ціли у співробітника фоормується своє уявлення результату (ідея два - 12). У підсумку може вийти, що керівник і співробітник по-різному уявляють собі одну й ту ж саму ціль (тобто I1 і I2 не збігаються). Щоб цього не відбулось, необхідно забезпечити зворотний зв'язок: досягти однозначного розуміння відповіді на запитання, чи правильно співробітник зрозумів поставлене перед ним завдання? Досягти однозначного розуміння відповіді на запитання, що саме треба отримати внаслідок виконання завдання. При цьому важливо прагнути до того, щоб було якомога менше понять, що приймаються "за замовчуванням". Інакше зростає ризик не досягти того, що задумане, особливо в нових і нестандартних ситуаціях. Красномовно можливість втрати інформації ілюструє схема, побудована на основі дослідження, що описане у Предрага Міціча, рис. 1 [5].

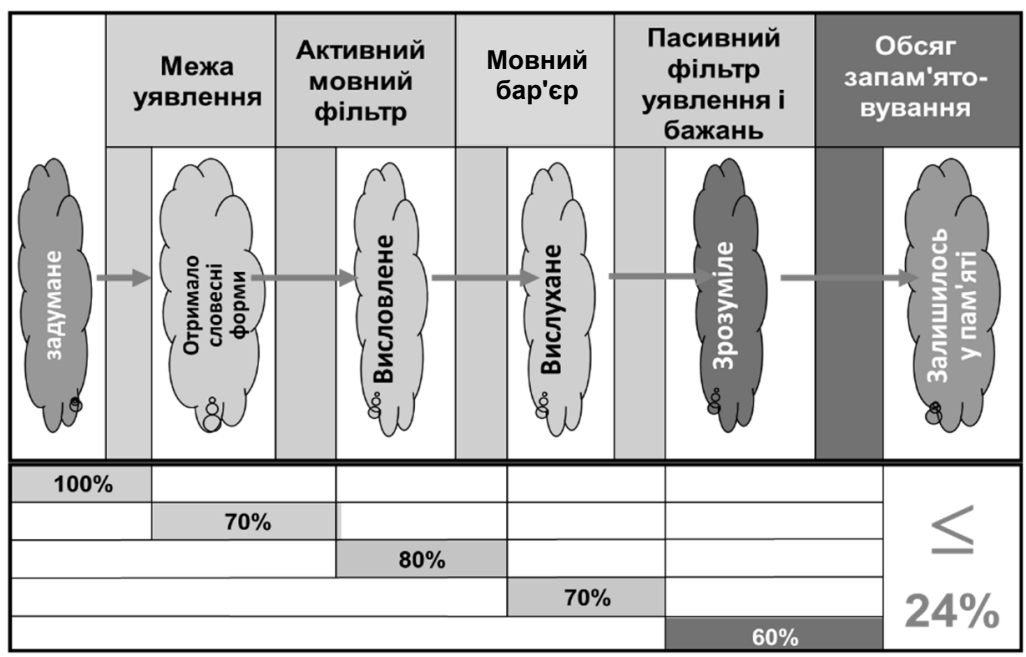

Рис. 1. Втрати інформації при розмовному спілкуванні двох співрозмовників (в одному напрямі)

Вимірюваність мети передбачає наявність критеріїв (вимірювачів), які дозволили б визначити, чи досягнено поставленої мети та якою мірою? Якщо нема вимірювачів, дуже складно оцінити результати виконаної роботи й об'єктивно контролювати процес. Критеріями досягнення цілі можуть бути: відсотки, співвідношення (цей критерій можна застосовувати для ситуацій, у яких $є$ можливість планувати й аналізувати повторювані події, (наприклад, при постановці цілі збільшувати кількість занять на виробничій базі, або із залученням фахівцівпрактиків); зовнішні стандарти (застосовуються у випадках, коли необхідно отримати сторонню оцінку, наприклад, при проведенні занять, критерієм їхньої якості може бути оцінка колеги з іншої кафедри, науково-методичного центру тощо; частота того, що відбувається (робота викладача може вважатися успішною, якщо його курс щороку обирає найбільша кількість студентів); середні показники (цей вимірювач можна використовувати, 
коли нема необхідності щось докорінно змінювати в результатах діяльності, потрібно лише забезпечити стабільність і якість роботи, наприклад регулярно готувати та проводити заняття на гідному рівні з дисциплін, які викладаються вперше; час (за який термін необхідно досягнути певних результатів, (наприклад, перейти на викладання окремих предметів іноземною мовою); заборони (неможна робити те й те, як наслідок буде покарання; це специфічний критерій, але його іноді можна успішно використовувати, наприклад - зменшити кількість запізнень, критерій, за кожне запізнення - стягнення); відповідність корпоративним стандартам (в організації розробляються свої стандарти), критерій відповідності: виконувати роботу так, як прийнято на кафедрі, факультеті; ствердження в керівництва (тобто "мені, керівникові, має сподобатись"; це може бути і суб'єктивна думка, але, якщо співробітник на момент отримання завдання знає, що використовується саме такий критерій оцінювання, то він прагнутиме отримати зворотній зв'язок у процесі виконання, наприклад, завдання - розробити методичні рекомендації із проведення педагогічної практики до 10 січня, критерій - "затвердити в мене").

Досяжність. При постановці завдань необхідно враховувати професійні можливості персоналу, як втримати баланс між напруженістю роботи й досяжністю результату. У цьому допоможе механізм встановлення планки цілей. Сутність його полягає в тому, щоб ставити персоналу такі цілі, які відповідають їхньому досвіду й індивідуальним особливостям. При цьому планка не повинна знижуватися та має зберігатися інтенсивний ритм роботи.

Перший варіант. У ситуації, коли необхідно підвищити загальні показники роботи колективу, до співробітника, що має й без того високі результати і такого, що ледь встигає виконувати обов'язки, необхідні різні підходи. Більш точне трактування слова "досяжність" стосовно контексту цілі, дозволяє говорити про параметр "індивідуально-досяжна", тобто ціль завжди повинна кидати виклик, виводити персонал із зони комфорту й занурювати його в зону зростання, при цьому, зберігаючи здатність реалізуватися за умови докладання зусиль. Для пояснення цього критерію виділимо декілька типів персоналу: досвідчений співробітник, амбітна "зірка"; досвідчений співробітник, ініціативний, помірно амбітний; досвідчений співробітник, прихильник стабільності, рутини; давно працюючий співробітник, безініціативний, невпевнений у собі; співробітник, щойно прийнятий на роботу.

Другий варіант - постановка цілі, при якій необхідно збільшити продуктивність діяльності, наблизившись до межі можливостей. Таке завдання підійде тим працівникам, що мають тривалий досвід роботи, успішно справляються зі своїми обов'язками, однак не шукають новизни й не мають бажання виділитися. Пряма установка на підвищення продуктивності праці хоча й може викликати деякий спротив із боку працівника, але повністю може виконуватися в міру його компетентності.

При третьому варіанті встановлення планки цілей ставиться завдання значно підвищити показники в роботі й наблизитись до межі можливостей. Досвідчені й ініціативні співробітники, що прагнуть кар'єрного зростання, уже завдяки бажанню домогтися більшого, готові до того, щоб працювати більш напружено й досягати більш високих результатів.

I нарешті, четвертий варіант - постановка цілі вище межі можливостей. Як уже можна зробити висновок, така мета підійде найбільш амбітним і таким, що вже багато чого досягли. Ці співробітники мають високі результати роботи, але для того, щоб залишатися першими, їм також необхідно підвищувати планку, ставити більш складні завдання, ніж ті, що вони вже розв'язували.

Отже, ураховуючи досвід і індивідуальні особливості, можна ставити персоналу такі завдання, делегувати такі повноваження, щоб при напруженому ритмі роботи вони могли досягати поставлених перед ними цілей.

Ще один із критеріїв постановки розумних цілей значущість. Розмірковуючи над тим, чи $є$ завдання значущим, треба відповісти на запитання, навіщо персоналу варто виконати це завдання, тобто, чому вона важлива для цілей більш високого рівня (аж до стратегічних). При формулюванні цілі необхідно заздалегідь визначити, для чого необхідне ії виконання. Це питання, "для чого?" треба ставити доти, доки не дійдемо до кінцевої відповіді приблизно такого змісту: "Тому, що саме це створить підстави для визнання моєї значущості, підвищить авторитет, зробить сенс діяльності більш змістовним тощо". Якщо саме це дасть персоналу усвідомлення значущості, керівник, на правильному шляху. У протилежному випадку, у кінці цього ланцюжка виконавець опиняється в ситуації невизначеності. А чи справді це потрібно було робити? У цьому варіанті розвитку подій треба терміново щось змінювати у формулюванні цілі, оскільки сходить на "нівець" іїі результат.

Висновки. 1. Ефективність управлінської праці керівника в закладі вищої освіти великою мірою залежить від особистісних характеристик керівника, але обов'язковим компонентом ії̈ продуктивності $€$ компетентності, які не можуть формуватися без спеціальних знань. Порядок обрання та призначення на посаду наявності таких знань не передбачає. Менеджер закладу освіти практично не може впливати на рівень передбачуваності завдань, які мають зовнішню природу, у той час як професійна організація й упорядкування структури внутрішньої діяльності дає значні переваги. Одним із напрямів оптимізації структури внутрішньої діяльності управлінця та підвищення ії ефективності $€$ готовність і уміння делегувати свої повноваження.

2. Найбільший резерв часу керівник може отримати, у межах добре спланованої роботи, за рахунок правильного делегування своїх повноважень: дотримання принципів делегування; чіткого розуміння виду й обсягу діяльності, робіт, які можна делегувати; чіткого розуміння порядку та процедури визначення цілей і постановки завдань; урахування професійних можливостей персоналу.

3. Важливою умовою ефективного делегування $€$ оволодіння керівником логікою формулювання та процедурою постановки розумних цілей, що має забезпечити напружений ритм для кожного працівника з урахуванням цілей діяльності, його особистісних і професійних можливостей.

\section{Список використаних джерел}

1. Жиленко М. В. Оцінка ефективності управлінської діяльності керівника закладу вищої освіти / М. В. Жиленко // Вісн. Київ. нац. ун-ту імені Тараса Шевченка. - Педагогіка. - 2018. - № 1 (7). - С. 11-14.

2. Жиленко М. В. Використання принципів нейролінгвістичного програмування при підготовці менеджерів для освітньої сфери / М. В. Жиленко // Вісн. Київ. нац. ун-ту імені Тараса Шевченка. - Педагогіка. - 2018. - № 2(8). - C. $17-20$.

3. Жиленко М. В. Організація особистої діяльності керівника, як умова ефективного управління закладом освіти / М. В. Жиленко // Вісн. Київ. нац. ун-ту імені Тараса Шевченка. - Педагогіка. - 2019. - № 2 (10). C. $60-65$

4. Закон України "Про вищу освіту" від 01.07.2014 року № 1556-18 // Відомості Верховної Ради України від 19.09.2014 - 2014 р. / № 37-38 /. С. 2716 , ст. 2004 [із змінами та доповненнями] [Електронний ресурс] //

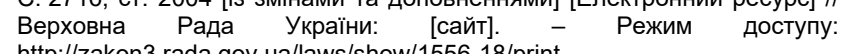
http://zakon3.rada.gov.ua/laws/show/1556-18/print

5. Мицич П. Как проводить деловые беседы / П. Мицич ; сокр. пер. с серб.-хорв. - 2-е изд. - М. : "Экономика", 1987.

6. Скібіцька Л.І. Організація праці менеджера : Навч. посіб. / Л. І. Скібіцька. - К. : Центр учбової літератури, 2010. - С. 137. 
7. Стандарт вищої освіти України. Рівень вищої освіти другий (магістерський) галузі знань 07 "Управління та адміністрування", спеціальності 073 "Менеджмент" [Електронний ресурс] // Міністерство освіти і науки України: [сайт]. - Режим доступу: (http://www.management.com.ua/ books/view-books.php?id=22)

References

1. Zhylenko M. V. Otsinka efektyvnosti upravlins'koyi diyal'nosti kerivnyka zakladu vyshchoyi osvity / M.V. Zhylenko // Visnyk Kyyivs'koho natsional'noho universytetu imeni Tarasa Shevchenka. - Pedahohika. - 2018. - № 1 (7). - S. 11-14

2. Zhylenko M. V. Vykorystannya pryntsypiv neyrolinhvistychnoho prohramuvannya pry pidhotovtsi menedzheriv dlya osvitn'oyi sfery / M. V. Zhylenko // Visnyk Kyyivs'koho natsional'noho universytetu imeni Tarasa Shevchenka. - Pedahohika. - 2018. - № 2(8). - P. 17-20.

3. Zhylenko M. V. Orhanizatsiya osobystoyi diyal'nosti kerivnyka, yak umova efektyvnoho upravlinnya zakladom osvity / M. V. Zhylenko // Visnyk
Kyyivs'koho natsional'noho universytetu imeni Tarasa Shevchenka. Pedahohika. - 2019. - № 2 (10). - P. 60-65.

4. Zakon Ukrayiny "Pro vyshchu osvitu" vid 01.07.2014 roku № 1556-18 // Vidomosti Verkhovnoyi Rady Ukrayiny vid 19.09.2014 - 2014 r., / № 37-38 /, stor. 2716, stattya 2004 [iz zminamy ta dopovnennyamy] [Elektronnyy resurs] II Verkhovna Rada Ukrayiny: [sayt]. - Rezhym dostupu: http://zakon3.rada.gov.ua/laws/show/1556-18/print

5. Mitsich P. How to conduct business conversations / P. Mitsich; abbr. per. with Serbian Horv. ; 2nd ed. - M. : "Economics", 1987.

6. Skibits'ka L. I. Orhanizatsiya pratsi menedzhera : navch. posibnyk. - K. : Tsentr uchbovoyi literatury, 2010. - P. 137.

7. Standart vyshchoyi osvity Ukrayiny. Riven' vyshchoyi osvity druhyy (mahisters'kyy) haluzi znan' 07 "Upravlinnya ta administruvannya", spetsial'nosti 073 "Menedzhment" [Elektronnyy resurs] // Ministerstvo osvity i nauky Ukrayiny: [sayt]. - Rezhym dostupu: (http://www.management.com.ua/ books/view-books.php?id=22)

Надійшла до редколегії 27.01.20

N. Zhylenko,Ph.D, Associate Professor

Taras Shevchenko National University of Kyiv, Kyiv, Ukraine

\section{CONDITIONS FOR EFFECTIVE DELEGATION OF POWERS BY THE MANAGER OF A HIGHER EDUCATION INSTITUTION}

The article deals with the level of readiness of the manager of the Free Economic Zone to delegate his powers and summarizes the experience of such activities. During the study of the activities of vice-rectors, heads of departments, deans of faculties, directors of institutes, educational and research centers of higher education, it was found that the head (manager), as a subject of management, must be able to analyze the situation, predict strategy, plan tactics to achieve defined goals and organize operational management for their implementation. But most of the respondents approach the solution of this problem at the level of everyday consciousness, do not always understand that management is first of all the ability to organize teamwork. The effectiveness of managerial work in a higher education institution largely depends on the personal characteristics of the head, but a mandatory component of its productivity are competencies that can not be formed without special knowledge. The procedure for election and appointment does not provide for the availability of such knowledge. The manager of an educational institution can hardly influence the level of predictability of tasks that have an external nature, while the professional organization and streamlining of the structure of internal activities provides significant advantages. One of the ways to optimize the structure of the internal activities of the manager and increase its efficiency is the willingness and ability to delegate their powers. This, as part of a well-planned work, gives the manager the greatest reserve of time. Analysis of the practice of successful managers and scientific literature on this issue, allowed to formulate and test recommendations to managers for successful delegation of authority, which involves the use of certain principles of delegation, a clear understanding of the types and scope of work, work that can be delegated; understanding the procedure and procedure for setting goals and setting goals; taking into account the professional capabilities of staff. It is proved that an important condition for effective delegation is the master's mastery of the logic of formulation and the procedure of setting reasonable goals, which should provide a busy rhythm for each employee, taking into account the goals and personal and professional capabilities.

Keywords: paradigm, branch of knowledge, speciality, educational program, subject area.

\section{ОСНОВНІ НАПРЯМИ ПСИХОЛОГІЧНОГО КОНСУЛЬТУВАННЯ В РОЗВ'ЯЗАННІ ВНУТРІШНЬООСОБИСТІСНИХ КОНФЛІКТІВ СТУДЕНТІВ І ВИКЛАДАЧІВ: ЗАРУБІЖНИЙ I ВІТЧИЗНЯНИЙ ДОСВІД}

Здійснено аналіз актуальних ідей із проблеми розв'язання внутрішніх конфоліктів студентів $і$ викладачів, що $є$ основою для педагогічних конфліктів у вищій школі. Особливий акцент поставлено на ресурсних можливостях напрямів психологічного консультування в розв'язанні внутрішньоособистісних конфліктів. Різні психологічні напрями, школи подають специфічні визначення, структуру, динаміку психологічного консультування. Увагу закцентовано на підвищенні рівня ефективності психологічного консультування та на самовідчутті кліснта. Процес консультування може здійснюватися в діапазоні від однісї до деякого кількості психологічних сесій. Наслідки консультування можна розглядати з погляду змін, що відбуваються в особистості клієнта, і ступеня його задоволеності результатами консультування. У цьому процесі виняткову увагу приділено еклектичній консультативній бесіді. Детально розглянуто її зміст, характеристику, принципи, специфіку, етапи, стадії. Узагальнено функції, мету, процедуру консультативної бесіди у вищій школі, що тлумачиться як динамічний процес, під час якого викладач-консультант допомагає студентові використати свої внутрішні ресурси для розвитку й актуалізації потенціалу осмисленого життя. Консультативна бесіда - суб'єкт суб'єктна взаємодія, яка будується та підтримується за партнерського стилю відносин; метою якого є взаємне збагачення досвідом, саморозвиток обох сторін і розв'язання проблем студента. Внутрішні конфлікти, які розв'язані конструктивно, позитивно впливають на особистість, забезпечують ї̈ подальше професійне зростання, вселяють віру в себе та в людей. Знання й базові компетентності з динаміки, специффіки внутрішніх конфліктів здатні заощадити час, зберегти продуктивність, здоров'я, підвищити креативність, професійну, інтелектуальну й особистісну компетентність студентів, викладачів і керівників закладів вищої освіти освіти. Деструктивно розв'язані коноллікти мають у собі протилежне й можуть призвести до неврозів, депресій, афективних станів, психічних захворювань, які, у свою череу, є ґрунтом для інших соматичних хвороб. Тому так важливо розв'язувати конфллікти 3 позитивним наслідком, який спричиняє, зокрема, доцільно вжитий інструментарій психологічного консультування.

Ключові слова: психологічне консультування, розв'язання внутрішньоособистісних конфліктів, педагогічні конфрлікти, студенти, викладачі.

Постановка проблеми. У наш складний час активної трансорормації, модернізації й інтеграції вищої освіти України та зарубіжжя постійно відбуваються пошуки нових міждисциплінарних парадигм, ефективних моделей насичених інноваційними технологіями професійного розвитку особистості студента. Новітні суспільні запити та 